R. Knight, J. L. Hardie, Dr. R. H. Thouless, Dr. C. A. Mace : Training the Mind" (Discussion: Section J). Miss I. Grier, J. B. Frizell, A. E. Henshall, D. E. Collier: Discussion on the Spens Report (Section L).

T. A.Wedderspoon, Dr. G. Cockerham, Dr. T. McIntosh : "Seed Potato Growing" (Discussion : Section'M).

At 10.30 a.m.-Dr. Mr. Macgregor, Dr. W. Q. Kennedy, Prof. G. Hickley, F.R.S., Prof. T. N. George, Prof. W. T. Gordon, Dr. T. S. Westoll : "The Boundary between the Old Red Sandstone and the Carboniferous" (Discussion: Section C).

At 2 p.m.-Colonel R. B. Campbell, Miss H. Drummond, Prof. A. Hemingway and H. R. Noltio: "Physical Fitness" (Discussion continued : Section I).

At 3.30 p.m. $\rightarrow$ N. F. Sheppard, Prof. H. J. Fleure, F.R.S. : "Anthropology in Education" (Discussion : Section H). At 8.30 p.m.-Dr. Isaiah Bowman : "Scienco and Social Pioneering" (British and American Association Lecture). Dr. D. A. Spencer : "Some Aspects of Colour-photography" (Public Lecture).

\section{Wednesday, September 6}

At 10 a.m.-Sir John Orr, F.R.S., L. Harris, D. Lubbock, Prof. P. Sargent Florence: Discussion on Nutrition (Division for Social and International Relations of Science)

\section{APPOINTMENTS VACANT}

AppLICATIOxs are invited for the following appointments, on or before the dates mentioned

REsidest ExaIseER (temporary) of a Small Arms Ammunition Factory at Cullane, Co. Clare-The Secretary, Department of Defence, Parkgate, Dublin, N.W.5 (September 8).

Assistaxt I.ecterer in the Sathematies and Physics Department -The Principal, Municipal Technical College, IIalifax (September 8). AsSistant Trassportatios SUPfRINTExidext (Rolling Stock) Traction Branch of the Great Indian Peninsula Railway-High Commissioner for India, General Department, India Iouse, Aldwych, W.C.2 (quoting 1/30A) (September 15).

LECTURER AND CHIEF DEMONSTRATOR IN ZOOLOGY in the Victoria University College, Wellington, New Zealand-The Secretary, Universitics Bureall of the British Empire, 88a Gower Street, W.C.1 (October 1).

Grandate Lectorer ix Mechasical Exgixeerixg in the Roval Technical College, Salford-The Director of Education, Education Office, Salford 3 , Lancs.

\section{REPORTS AND OTHER PUBLICATIONS}

\section{(not included in the monthly Books Supplement)}

Great Britain and Ireland

Home Office, Ministry of Health and Scottish Office. Final Report of the Inter-Departmental Committee on the Rehabilitation of Persons Injured by Accidents. Pp. vi $+194+8$ plates. (London: H.3I Stationery Oifice.) $38.6 d$. net.

County Council of the West Riding of Yorkshire. Report on a Study of the Diets of 205 Families in the West Riding of Yorkshire. Pp. 26. (Wakefleld : County IIall.)

$[123$

The Harper Adams Adviser. Advisory Report Fo, 1t: A Review

(Newport, Shropshire: Harper Adams Agricultural College.) Pp. 20.

Seventy-fifth Annual Report on Alkali, etc. Works. By the Chief Inspectors. Proceedings during the Year 1938. Pp. iii +59. (London Forestry Commission. Bulletin No. 14 (revised 1939): Forestry Practice ; a Summary of Methods of Establishing Forest Nurserie and Plantations with Advice on other Forestry Questions for Owner and Agents. Pp. 99. (London: II.M. Stationery Office.) 1s. 6d. Edinburgh and East of Scotland College of Agriculture. Calendar for 1939-1940. Pp. 96. (Edinburgh: Edinburgh and Fast of Scotiand College of Agriculture.)

[218

British Association for the Advancement of Scicnce. A Scientific Survey of Dundee and District. Prepared for the Dundee Heeting,
1939 , by various Authors. Edited by R. L. Hackic. Pp. 124. (London 1939, by various Authors. Edited by R. L. Hackic. Pp. 124. (London
British Association.)

British Association for the Advancement of Science, Dunde Meeting, August 30-September 6, 1939. Official Guide to the Cit and its Environs. Edited by R. J. Mackie and J. B. Salmond (Published for the Local Executive Committce.) Pr. 136. (Glasgow
John Jenzies and Co.. Ltd.)

\section{Other Countries}

The Rockefeller Foundation. Annual Report, 1938. Pp. $\mathbf{x}+515$ New York: The Rockefeller Foundation.) Union of South Africa: Department of Hines, Geological Survey. The Geology and Mineral Deposits of the Omaruru Area, South West Africa: an Explanation of Sheet No. 71 (Omaruru, S. W.A.). By Schwelinus and P. J. Rossour. Pp. 152. (Pretoria: Government Printer.) 5s., including Map. Department of Agriculture, Mauritius: Sugarcane Rescarch Station. Bulletin No. 15: The Inheritance of Gumming Disease Resistance in Sugarcane Breeding. By G. C. Stevenson. Pp. 9. (Port Tanganyika Territory. Department of Lands and Manes: Lard Division. Annual Report 1938. Pp. 12. 18. Department of Lands Division. Annual Report 1938. Pp. 12. 18. Department of Lands
and Hines: Mlines Division. Annual Report 1938. Pp. 36. 18. and Mines: Mfines Division. Annual Report 1938. Pp. 36. 18. 1938. Pp. 22. 18. (Dar es Salam : Government Printer.) Report
[128 Annual Report of the Public Health Commissioner with the Government of India for 1937. Vol. 2. Pp. vit157. (Delhi: Manager of
Publications.) 2.6 rupees; 48.
[143 Smithsonian Miscellancous Collections. Vol. 98, No. 21: The Weckly Period in Washington Precipitation. By C. G. Abbot and N. M. McCandlish. (Publication 3547.) Pp. ii +4. (Washington, D,C.
Smithsonian Institution.)

U.S. Department of the Interior: Office of Education. Bulletin 1938, No. 11: Principles and Procedures in the Organization of Satisfactory Local School Units, By Henry F. Alves and Edgar $\mathbf{L}$ Morphet. (Local School Units Project.) Pp. vii +164. (Washington,
D.C.: Government Printing Office.) 25 cents. Bulletin of the Department of Zoology, Panjab University, Vol. 2 Fauna of the Dal Lake, Kashmir. 1: On some Leeches from the Da Lake, Kashmir. By Dr. M. L. Bhatia. Pp. $1 \mathbf{i}+1$ plate. (Lahore:
University of the Panjab.) i rupee. Pasteur Institute of India. The Thirty-seventh Annual Report of the Dircetor of the Institute for the Year 1937. Part 2. Pp. 46. (Kasauli : Pasteur Institute of India.)

Tanganyika Territory. Department of Lands and Mines: GeoIogical Division. Annual Report 1938. Pp. 27. (Dar es Salaam :
Government Printer.) 18. 6d.

Conseil Permanent International pour l'Exploration de la Mer. Rapports et procés-verbaux des réunions. Fol. 110 : Contributions to Special Scientific Meetings, 1939. Pp. 112. (Copenhague: Andr.
Fred. Host et fls.) $6.00 \mathrm{kr}$. Geological Survey of British Guiana. Bulletin No. 13: Report on a Short Visit to Marudi Mountain fold Workings, Rupununi District, 1934. By Dr. D. 12. Grantham. Pp. ii $+5+1$ plate. (Georgetown Gcological Survey.) 12 cents.

Report of the Haffkine Institute for the Year 1938. By Lt.-Col. S. S Sokher. Pn. iil +90. (Bombay: Government Printing and Stationery Office.) 3 annas; 4 . . [168 Government Museum, Trivandrum. Annual Report, 1113 M.E. Pp. 8. (Trivandrum : Government Museum.) [16S Smithsonian Miscellancous Collections, Vol. 98, No. 29: The Determination of Small Amounts of Chlorophyll-Apparatus and Yethod. By Earl S. Johnston and Robert L. Weint raub. (Publication 3515.) Pp. ii $+6+2$ plates. (Washington, D. C.: Smithsonian Smithsonian Institution: United States National Juseum. ConSmithsonian Institution: United States National suseum. Con-
tributions from the United States National Herbarium, Vol. 26, tributions from the United States National Herbatium, Vol. 26,
Part 9: A Revision of Besleria. By C. V. Morton. Pp. vi $+395-474+$

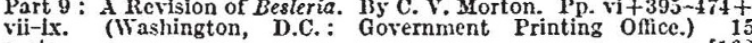
cents.

U.S. Department of Agriculture. Farmers Bulletin No. 1828: Grasshoppers and their Control. By J. R. Parker. Pp. ii +38 . (11 ash
ington, D.C. : Government Printing Office.) 10 cents. American Anatomical Memoirs. No.18: A Resurvey of the Developments of Lymphatics and Associated IBlood Vesscls in Anuran Amphibia by the Yethod of Injection. By I Ienry MeElderry Knower. P'p. 125 (19 plates). (Philadelphia : Wistar Institute of Anatomy and 125 (19 plates). (Philadelphia: Wistar Institute of Anatomy and
Biology.) N.Z. Department of Scientific and Industrial Research: Apia Observatory, Apia, Western Samoa. Annual Report for 1935. Pp.
145. (Wellington: Government Printer.) 68. U.S. Department of the Interior: Office of Education. Vocational Division Monograph No. 20 : Discovering Occupational Opportunities for Young Yen in Farming. By J. W. Hatch. Abbreriated and rearranged by F. W. Lathrop. Pp. Iv +9. (Washington, D.C. : GorernCommonwealth of Australia: Department of Health. Physical Aspects of Radium and Radon Therapy. By Dr. C. E. Eddy and Aspects of Radium and Radon Therapy: By. Dr. C. E. Eddy and
T. I. Oddie. Second edition. Pp. $5 \%$ (Canberra: Government.
Printer.)
[21s

Survey of India. Geodetlc Report, 1938. Pp. iv+86+11 charts
[218

Royal Observatory, IIong Kong. Meteorological Results, 1938. Prepared under the direction of C. W. Jeffries. Pp. $1 v+142+11+6$. 3 dollar3. Report of the Director for the Year 1933. Pp. 8. 30 cents (Hong Kong: Royal Observatory.)

Publikationer fra det Danske Metcorologiske Institut: Aarboger. Isforholdene 1 de Arktiske Have (The State of the Ice in the Arctic Seas) 1938. Prepared by Helge Thomsen. Pp. 17+5 maps. (Koben-
hasn: G. E. C. Gad.)
[218 U.S. Departure of Agriculture. Lcaflet No. 184: The Elm Icaf Beetle. By C. W. Collins. Pp. 6. 5 cents. Miscellaneous Publication No. 341: The Species of Pantomorus of America North of Jexico. my L. Lut Buchanan. Pp. 40. 10 cent3. (Washington, D.C.: Govern 